PART I. DISEASES AND PROBLEMS DISTINGUISHED BY WHO AND FAO DZIAŁ I. CHOROBY I PROBLEMY WYRÓŻNIONE PRZEZ WHO I FAO

\title{
BREAST CANCER RISK FACTORS - AWARENESS AND ATTITUDES OF WOMEN IN PERIMENOPAUSAL AND POSTMENOPAUSAL AGE (45+) IN POLAND
}

\section{CZYNNIKI RYZYKA W RAKU PIERSI - ŚWIADOMOŚĆ I POSTAWY KOBIET W WIEKU OKOŁO I POMENOPAUZALNYM (45+) W POLSCE}

\author{
Paweł Koczkodaj ${ }^{1,2(A, B, C, D, E, F)}$, Marta Mańczuk $^{1(A, C, D, E)}$, Joanna Gotlib ${ }^{2(D, E)}$ \\ ${ }^{1}$ Oncology Center - the Maria Skłodowska-Curie Institute of Oncology, Warsaw, Poland \\ ${ }^{2}$ Medical University of Warsaw, Poland
}

Authors' contribution

Wkład autorów:

A. Study design/planning

zaplanowanie badań

B. Data collection/entry

zebranie danych

C. Data analysis/statistics

dane - analiza i statystyki

D. Data interpretation

interpretacja danych

E. Preparation of manuscript

przygotowanie artykułu

F. Literature analysis/search

wyszukiwanie i analiza literatury

G. Funds collection

zebranie funduszy

\section{Summary}

Background. Breast cancer (BC) is the most common malignant cancer among women in Poland. As we do not have sufficient knowledge about origin of this disease, women's awareness and attitudes concerning the few well-known BC risk factors play a key role in the prevention and early detection of BC.

Material and methods. The questionnaire was answered by 380 women, 45 years and older in Poland between May and August 2017. This randomly selected research group included subjects with a prior history of $\mathrm{BC}$, a current diagnosis of $\mathrm{BC}$, and healthy women without any history of $\mathrm{BC}$ in the past. Women were asked about their knowledge and attitudes concerning $\mathrm{BC}$ risk factors. Collected data were analyzed using Microsoft Excel, taking into account place of residence and education level.

Results. Among probable BC risk factors, the most commonly indicated by the women were gene mutations (60\%), long-term use of hormonal contraception (49\%) and overweight and obesity (38\%). The most rarely indicated factors were late full-term pregnancy $(12 \%)$, childlessness $(21 \%)$ and alcohol consumption (26\%). About $72 \%$ of the respondents assessed their knowledge about BC as good or very good, but only $41 \%$ of this group indicated overweight and obesity - one of the strongest risk factors - as contributing to BC. Moreover, only $26 \%$ of women who assessed themselves as having a high level of knowledge perceived alcohol consumption as a risk factor.

Conclusions. Results suggest that education in this age group should be more efficient and more focused on raising awareness about well-known BC risk factors.

Keywords: breast cancer, primary cancer prevention, risk factors, menopause

\section{Streszczenie}

Wprowadzenie. Rak piersijestnajczęściej występującym nowotworem złośliwym wśród kobiet w Polsce. Ponieważ nadal nie mamy pełnej wiedzy dotyczącej etiologii tej choroby, świadomość kobiet oraz ich postawy odnoszące się do kilku dobrze poznanych czynników zwiększających ryzyko raka piersi pełnią kluczową rolę w jego prewencji i wczesnym wykrywaniu.

Materiał i metody. W okresie od maja do sierpnia 2017 r. przeprowadzono ustrukturyzowany wywiad pośród 380 kobiet w Polsce (w wieku 45 lat i starszych). Losowo dobrana grupa badawcza składała sie z kobiet, które miały lub mają raka piersi, oraz zdrowych kobiet, bez historii choroby. Badane kobiety zostały zapytane o ich wiedzę oraz postawy dotyczące czynników ryzyka $w$ raku piersi. Zebrane dane zostały poddane analizie przy użyciu oprogramowania Microsoft Excel, biorąc pod uwagę również takie informacje, jak miejsce zamieszkania i poziom wykształcenia kobiet.

Wyniki. Najczęściej wskazywanymi przez kobiety czynnikami ryzyka, jako prawdopodobnie przyczyniajacymi się do wystapienia choroby, były: mutacje genowe - 60\% (228), przedłużone stosowanie hormonalnej terapii zastępczej (HTZ) - 49\% (186) oraz nadwaga i otyłość 38\% (137). Najrzadziej: późna ciąża - 12\% (46), bezdzietność - $21 \%$ (80), spożywanie alkoholu $26 \%$ (99). Swoją wiedzę dotyczącą raka piersi, jako dobrą lub bardzo dobrą oceniło $72 \%$ (274) badanych kobiet. W tej grupie tylko 41\% (112) wskazało nadwagę i otyłość - jeden z najważniejszych czynników ryzyka. Tylko $26 \%$ wśród kobiet z wysoką samooceną wiedzy nt. choroby postrzegało spożywanie alkoholu jako czynnik ryzyka.

Wnioski. Wyniki badania sugerują, że edukacja w tej szczególnej grupie wiekowej kobiet powinna być bardziej efektywna i kładąca więcej nacisku na wiedzę dotyczącą czynników ryzyka w raku piersi.

Słowa kluczowe: rak piersi, prewencja pierwotna nowotworów, czynniki ryzyka, menopauza
Figures: 4

References: 27

Submitted: 2019 Feb 3

Accepted: 2019 Apr 1

Koczkodaj P, Mańczuk M, Gotlib J. Breast cancer risk factors - awareness and attitudes of women in perimenopausal and postmenopausal age (45+) in Poland. Health Prob Civil. 2019; 13(4): 239-247. https://doi.org/10.5114/hpc.2019.84191

Address for correspondence / Adres korespondencyjny: Paweł Koczkodaj, Oncology Center - the Maria Skłodowska-Curie Institute of Oncology, Wawelska 15B, Address for correspondence / Adres korespondencyjny: Paweł Koczkodaj, Oncology
02-034 Warsaw, Poland, e-mail: pawel.koczkodaj@gmail.com, phone: +48 225709478

Copyright: (C) Pope John Paul II State School of Higher Education in Biała Podlaska, Paweł Koczkodaj, Marta Mańczuk, Joanna Gotlib. This is an Open Access journal, all articles are distributed under the terms of the Creative Commons Attribution-NonCommercial-ShareAlike 4.0 International (CC BY-NC-SA 4.0) License (http:// creativecommons.org/licenses/by-nc-sa/4.0/), allowing third parties to copy and redistribute the material in any medium or format and to remix, transform, and build upon the material, provided the original work is properly cited and states its license. 


\section{Introduction}

Breast cancer (BC) is the most common type of malignant cancer in women around the world and one of the main cause of cancer death among women [1]. World Health Organization (WHO) estimates that about 2.1 million women have breast cancer yearly, with 627,000 deaths in 2018 (approximately 15\% of all cancer deaths among women globally) [2].

According to the latest epidemiological data from the National Cancer Registry in Poland, 18,615 new BC cases were diagnosed (ASW/100,000 $=54.1$ ) in 2016. During the same time period, 6,493 deaths were caused by BC (ASW/100,000 = 14.9). BC was the second leading cause of cancer deaths among women in Poland. Since 2007, lung cancer has caused more deaths, however since 2010 there has been an increase in BC mortality. Moreover, in 2016 in Poland $14.5 \%$ of all cancer deaths among women were caused by BC [3].

$\mathrm{BC}$ risk increases with age. This disease is most common for women at about the age of 50 . Approximately $80 \%$ of all $\mathrm{BC}$ cases occur in the perimenopausal phase of life. However, during the last three decades, the incidence among younger women (20-49 years of age) has increased as well [4]. The relationship of age and BC incidence is also reflected in epidemiological data from the years 1999-2016 (Figure 1). BC incidence grows dramatically among women starting at age 40 , and reaches a peak at about the sixth decade of life. Moreover, the risk of death due to BC increases with women's age as well (Figure 2).

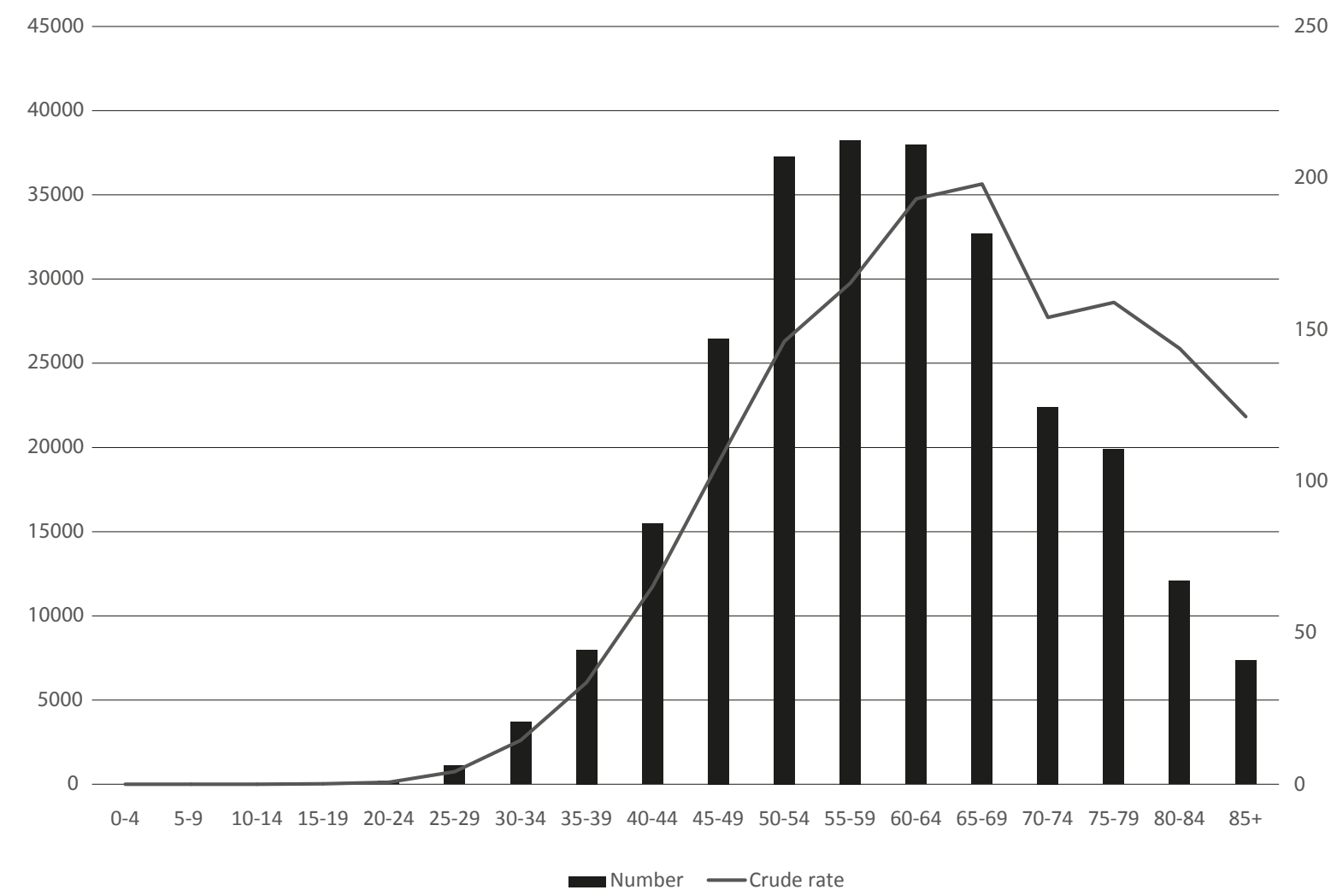

Figure 1. Breast cancer incidence by age groups in Poland in the years 1999-2016 (based on data from the National Cancer Registry in Poland, www.onkologia.org.pl) 


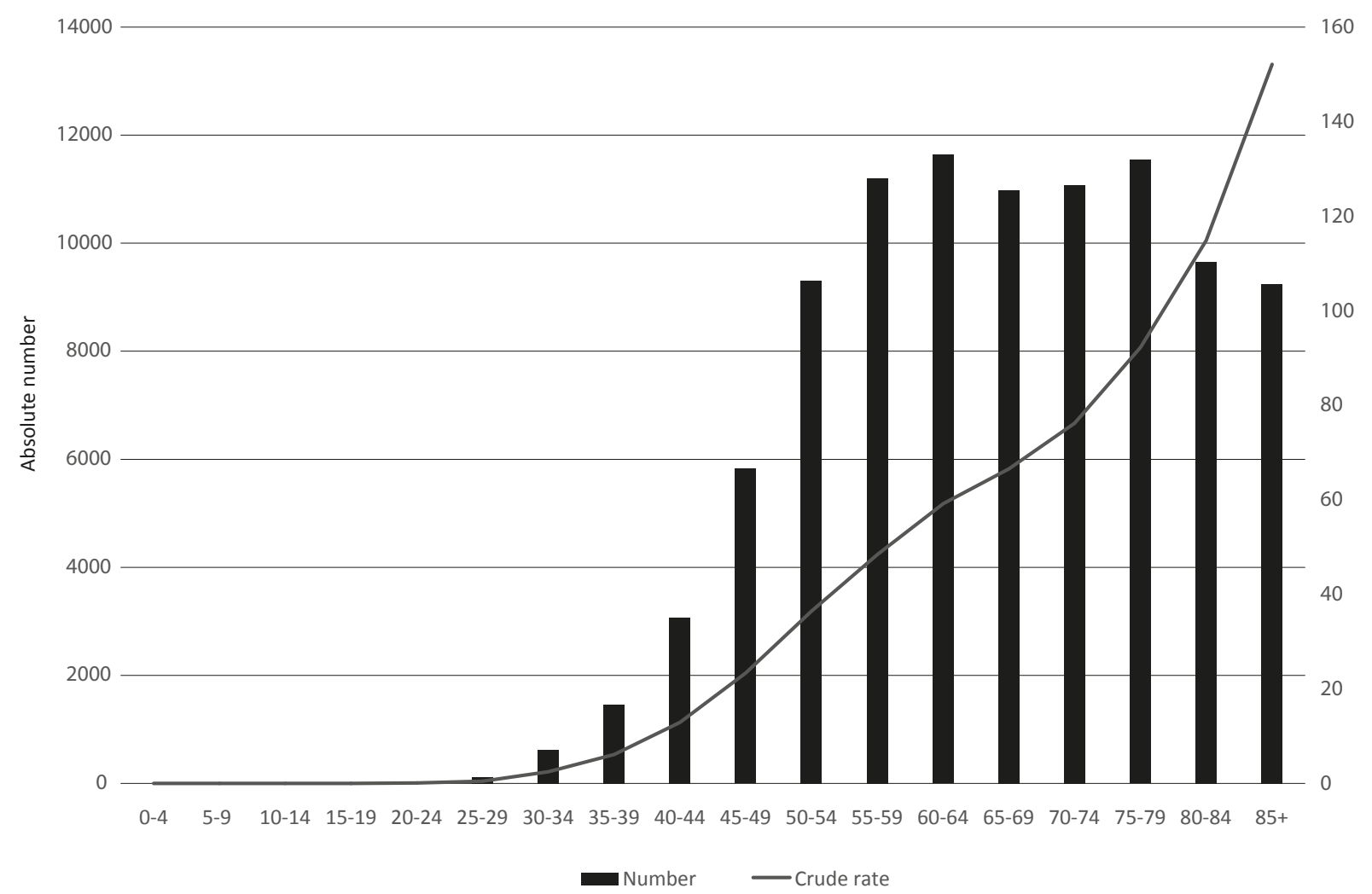

Figure 2. Breast cancer mortality by age groups in Poland in the years 1999-2016 (based on data from the National Cancer Registry in Poland, www.onkologia.org.pl)

Aging is one of the most important risk factors for all cancers, and this is also true for BC, as indicated in Figure 1. Nevertheless, apart from age, there are also well-known risk factors which have been identified as significant for BC development and which can be modified or eliminated. It has been estimated that $90-95 \%$ of all malignant cancers are caused by external factors connected with lifestyle while only 5-10\% are primarily caused by genetics [5].

Overweight and obesity increase BC risk significantly, especially among postmenopausal women. The National Cancer Institute in the United States indicates that increased Body Mass Index (BMI) is undoubtedly one of the most powerful BC risk factors: a 5-unit increase in BMI results in about a 12\% higher BC risk. Moreover, postmenopausal women with obesity present a 20-40\% higher BC risk as compared to women at the same age but with regular weight [6]. About $50 \%$ of women who develop BC at an older age are also diagnosed with obesity. It has been estimated that the prevention of overweight could decrease the annual BC incidence rate in Europe by as much as $50 \%[7]$.

Another modifiable BC risk factor which is closely related to overweight and obesity is insufficient physical activity. In one study, women who were physically active had a BC risk $25 \%$ lower than those who were physically inactive [8]. The American Cancer Society stressed that this effect is especially visible among women after menopause [9].

Epidemiological data has proved that alcohol consumption is clearly linked with a higher BC risk. Drinking 1-2 drinks a day (15-30 grams of alcohol/day) increases BC risk about 30-50\% in comparison with women who are abstainers [10]. This relation is observed among women both before and after menopause [11].

Among the other modifiable BC risk factors are also: prolonged use of hormonal replacement therapy (HRT), late full-time pregnancy (after the age of 30-35), and not having children. These all increase the overall risk of $\mathrm{BC}[8]$.

$\mathrm{BC}$ is a notably heterogeneous disease. Often it is caused by combination of variable risk factors - modifiable and not modifiable. As we still don't have sufficient knowledge about the origin of this disease, it is crucial to reduce exposure to well-known risk factors in order to decrease BC incidence and mortality as much as possible. 


\section{Material and methods}

Data was collected with a questionnaire constructed specifically for the purpose of this study, addressed to women in the perimenopausal and postmenopausal ages. The inclusion criterion was the age - equal to or higher than 45 years old. Participants were selected randomly. The respondents included healthy women who never had been diagnosed with BC, women who had a history of BC or other cancer type, and women with BC at the moment of the study. The survey was sent to over 75 regional centers of the Amazons Associations, to the Polish Oncology Patient Coalition, 25 Universities of the Third Age, 4 women's associations and employees of the Central Statistical Office in Warsaw. Due to the specificity of the target group, the study applied both CAWI (Computer-Assisted Web Interview) methodology and the traditional PAPI (Paper and Pen Personal Interview) methodology. The questionnaire consisted of 26 single- and multiple-choice questions divided into following sections: breast cancer - previous treatment, breast cancer education, and prevention (regarding risk factors). Questions concerned the participants' perception of specific factors, as protecting from or predisposing to development of BC, health behaviors of women, their hormonal status, as well as socio-demographic profile (education, place of residence, etc.). Interviews were collected from May to August 2017. The final cohort of participants included 380 women. Subsequently, a database has been created: all the data were coded and preliminarily analyzed using Microsoft Excel ver. 15.22 (160506), taking into account the socio-demographic profile of the respondents.

\section{Limitations of the study}

Not all of the questions in the questionnaires were answered (obligatory fields). Especially in the case of the PAPI version of the questionnaire, some of the data was missing (e.g. place of residence, date of birth, education level, etc.). Some of the questionnaires (paper version) also contained so-called "transition errors" where participants answered questions they should not have, for example when healthy women answered questions meant for cancer survivors. These surveys were not taken on to further analysis.

\section{Results}

The final research cohort consisted of 380 women aged 45 years and older. In this investigated group, 58\% of women (219) were former or current BC patients (BC group). 42\% (158) were healthy, without history of BC (non-BC group). The average age in the BC group was 63 and in the non-BC group 58. The oldest participant was 82 at the time of the study. The great majority of women who took part in the study were living in cities - $86 \%$ (188) and 88\% (139) respectively in the BC and non-BC group. Lower education levels were more characteristic for the BC group - 31\% (68) declared higher educational status. Women from the non-BC group more often were recipients of education about $\mathrm{BC}$ risk factors, as well as early detection of this disease. Moreover, these women were more satisfied with the level of education which they had (40\% (63) vs. 34\% (74) in BC group). Almost the same percentage of women from the BC and non-BC groups declared participation in screenings - 84\% (184) and $85 \%$ (134) (Table 1).

Table 1. Characteristics of participants

\begin{tabular}{|c|c|c|}
\hline Characteristics & $\begin{array}{c}\text { BC survivors/patients } \\
58 \%(\mathrm{~N}=219)\end{array}$ & $\begin{array}{c}\text { Healthy women } \\
42 \%(\mathrm{~N}=158)\end{array}$ \\
\hline Average age (years) & 63 & 58 \\
\hline Place of residence - city & $86 \%(188)$ & $88 \%(139)$ \\
\hline Place of residence - village & $14 \%(31)$ & $11 \%(17)$ \\
\hline Higher education & $31 \%(68)$ & $63 \%(99)$ \\
\hline $\begin{array}{l}\text { Completion of education about BC } \\
\text { risk factors }\end{array}$ & $42 \%(92)$ & $57 \%(90)$ \\
\hline $\begin{array}{l}\text { Completion of education about early } \\
\text { detection of BC }\end{array}$ & $46 \%(101)$ & $59 \%(93)$ \\
\hline $\begin{array}{l}\text { Women satisfied with the level of } \\
\text { education about BC risk factors and } \\
\text { early detection }\end{array}$ & $34 \%(74)$ & $40 \%(63)$ \\
\hline Declared participation in screenings & $84 \%(184)$ & $85 \%(134)$ \\
\hline
\end{tabular}


96\% (367) of women answered the question about their self-assessment of BC risk factors. 72\% (274) assessed their own knowledge in this matter as very good or good, 20\% (75) as average and 5\% (18) - as low or none. It was then calculated whether women from the above three subgroups perceived selected BC risk factors as increasing risk of the disease (Figure 3). Moreover, we analyzed the attitudes of women on well-known BC risk factors in their daily life in the same three subgroups (Figure 4).

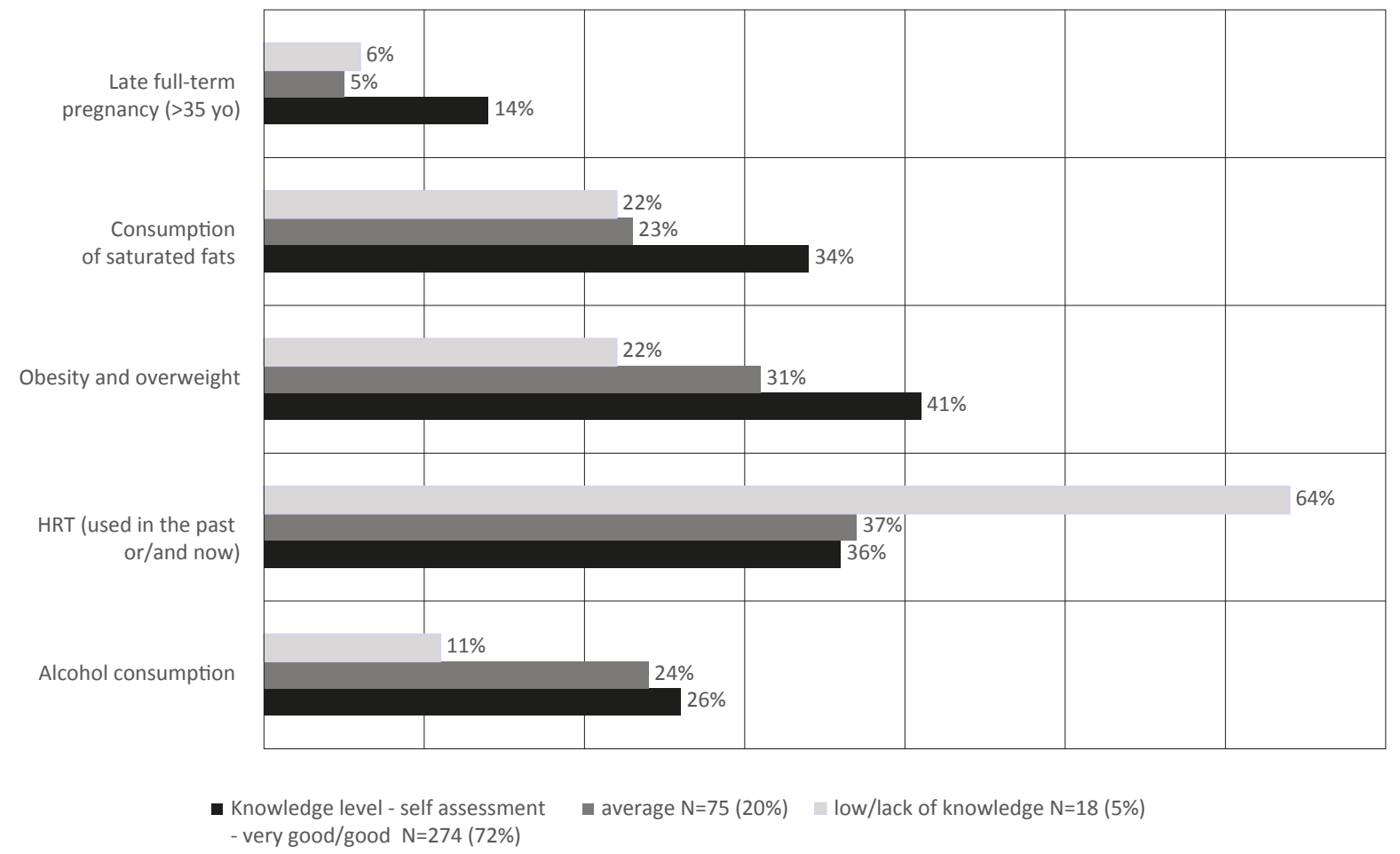

Figure 3. Risk factors for BC accurately perceived as BC risk factors by women who assessed their knowledge about BC as very good/good, average, or low/lack of knowledge

The data indicates significant differences in women's perception of specific factors as increasing BC risk (Figure 3). Among women who assessed their knowledge about BC as very good/good only 41\% (112) of them indicated overweight and obesity - one of the strongest risk factors - as contributing to BC. In the same group only $26 \%$ (71) of women perceived alcohol consumption as a factor increasing this risk. In the group of women who assessed their knowledge as average, 31\% (23) claimed that obesity and overweight contribute to BC, and $24 \%$ (18) thought that alcohol has an influence on BC occurrence. Women who assigned themselves to the group with a low level of knowledge or lack of knowledge about BC, in 22\% of cases (4) assessed overweight and obesity as an important factor for BC risk, while 11\% (2) indicated alcohol consumption.

For these two risk factors (overweight and obesity, and alcohol consumption) the tendency is similar - the higher women assessed their knowledge of BC, the more frequently they accurately indicated the specific BC risk factor. The same situation was observed for the consumption of saturated fats.

On the other hand, there were two risk factors for which the tendency was different. A completely reverse relationship is seen in the ability to accurately indicate HRT use as a breast cancer risk factor. 64\% (12) of women from the group with lowest self-assessment of knowledge about BC perceived HRT use as an important factor for BC development, which is the highest percentage for all groups of respondents and all BC risk factors. In the group of women who assessed their knowledge as average and good/very good it was respectively $37 \%$ (28) and 36\% (27) of women.

$14 \%$ (38) of women who assessed their knowledge of BC as good/very good perceived late full-term pregnancy as a significant risk factor. Only 5\% (4) and 6\% (1) of women from groups with an average and low knowledge recognized this factor as increasing the risk. 


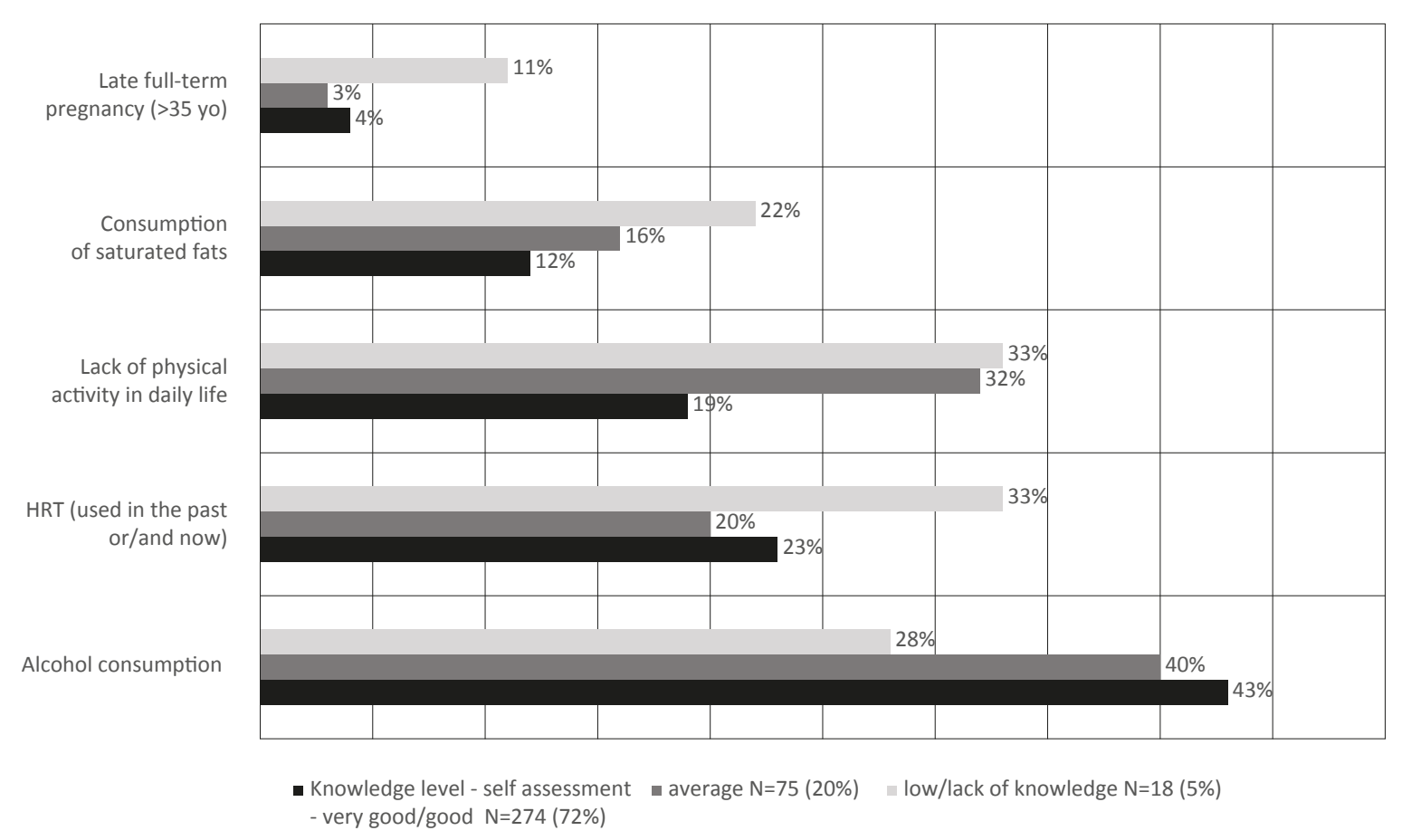

Figure 4. Personal exposure to modifiable BC risk factors presented by women who assessed their knowledge about BC as very good/good; average; low/lack of knowledge

The results showed also a lack of visible reflection between declared level of knowledge about BC and presented attitudes of women regarding the analyzed risk factors (Figure 4). As many as $43 \%$ (118) of women who assessed their knowledge as good/very good declared regular alcohol consumption as well. Moreover, in the same group almost $1 / 5$ of women were physically inactive (52). Similarly, in the group of women who assessed their knowledge as average, as many as $40 \%$ (30) of them admitted that regularly drink alcohol. Also, in this group nearly $1 / 3$ of women (24) were physically inactive. Almost the same percentage - 33\% (6) has been observed among women with declared low/lack of knowledge about BC. What is significant, women who declared the lowest knowledge level of BC at the same time demonstrated the lowest alcohol consumption - 28\% (5) - in comparison with women with self-assessed average and good/very good levels of knowledge.

Additionally, our results described the women's knowledge regarding BC screenings. In the group of women who assessed their knowledge of BC as good/very good, only 25\% (69) indicated the correct frequency of mammography (every two years). In the same group, about 52\% (142) of women declared performing breast self-examination once a month. In the group with declared average knowledge level it was respectively $31 \%$ (23) for mammography and 35\% (26) for breast self-examination. In the group with the admitted lowest level of knowledge on BC or lack of knowledge at all, 44\% (8) of women indicated the correct answer about mammography frequency and $17 \%$ (3) about breast self-examination.

With reference to education level, the largest percentage of women who performed breast self-examination once a month were those with the lowest level of education (primary education) - 65\% (11). In the groups with secondary and higher education it was respectively $54 \%$ (102) and $38 \%$ (60) of women.

\section{Discussion}

Current activities to prevent BC at the national level in Poland are focused on secondary BC prevention, which is concentrated on mammography for women in the 50-69 year-old age group [12]. However, in order to decrease $\mathrm{BC}$ incidence, especially among women in the highest risk age group (perimenopausal and postmenopausal) it is crucial to focus also on primary cancer prevention, that is decreasing exposure to well-known $\mathrm{BC}$ risk factors.

In our study we showed that the perception of specific risk factors as increasing $\mathrm{BC}$ risk varies significantly. Surprisingly, only $26 \%$ (71) of women who assessed their knowledge as good or very good $(\mathrm{N}=274,72 \%)$ perceived alcohol consumption as an important BC risk factor. In the same group, 43\% (118) of women drank alcohol. Jokiel and Bielska-Lasota indicate in their study that daily alcohol intake, even in small doses, can increase the risk of BC, up to about 11\% [13]. Similarly, Thazibi and Feizi showed that alcohol consumption is one 
of the few well-established BC risk factors [14]. A study by Shield et al. showed that globally, the incidence and mortality of alcohol-attributable BC is significant [15]. Moreover, referring to the data from the State Agency for the Prevention of Alcohol-Related Problems in Poland (PARPA) about 80\% of women in Poland drink alcohol. The highest consumption has been observed in the young age group (18-29 years old) [16]. However, the overall high alcohol consumption level in the population of Polish women is reflected also in our own study, albeit in a different age group.

Another important factor which significantly increases BC risk is overweight and obesity. 41\% (112) of women who assessed their knowledge of BC as good/very good indicated that overweight and obesity is an important BC risk factor. At the same time, 19\% (52) of women from this group admitted that they are physically inactive in daily life. Similarly, as in the case of alcohol consumption, the presented percentages (41\% and 19\%) seem to not support the self-assessed knowledge level of this group. Neuhouser et al. showed in the study performed among women in the postmenopausal age group $(\mathrm{N}=142)$ that there is a clear relationship between increased invasive $\mathrm{BC}$ risk and presence of overweight and obesity [17]. La Vecchia et al. in their study also indicated that BC among postmenopausal women is linked with overweight and obesity. Additionally, researchers highlighted a reverse relationship between overweight and BC occurrence among premenopausal women [18].

Today, overweight and obesity are becoming a more and more severe health problem in Poland. In 2014, $53.3 \%$ of the Polish population aged 15 or older was overweight or obese. Of women in this study, $30.1 \%$ of women were overweight and $15.6 \%$ were obese [19]. Moreover, results of the study conducted by the Polish Central Statistical Office showed that in Poland, people with a higher BMI mostly are aged approximately 50 years old [20], which has significance with reference to the BC incidence. The World Health Organization estimates that approximately $21-25 \%$ of BC cases worldwide are linked to physical inactivity [21]. In our research group, this factor was highly visible - especially among women who assessed their level of knowledge about BC as average or low/lack of knowledge - in these two groups it was respectively $32 \%$ (24) and 33\% (6) of women who were physically inactive in their daily life. Similar to the WHO, Lynch et al. indicated in their study that physical activity results in a $25 \%$ reduction in $\mathrm{BC}$ risk. The activity brought the best health effects for women who were active regularly through the lifetime or started activity after menopause [22]. With reference to WHO data, physical activity at an adequate level in Poland is very low. In 2014, only 15.5\% of women (15 years and older) were physically active (the number rises to $18 \%$ if we include physical activity connected with transport) [23]. These data are also reflected in own results - we observed a high percentage of physically inactive women in our investigated age group.

In order to decrease BC mortality rates, apart from primary cancer prevention, secondary prevention also has significant meaning. Basic methods - mammography and ultrasound examination - are without a doubt first and crucial actions which should be taken by women at certain age and risk groups [2, 24, 25, 26]. Nevertheless, "cancer vigilance" expressed through carrying out breast self-examination has also a great value. In our study, the majority of women who performed breast self-examination once a month had only a basic level of education (primary education) - 65\% (11). In the groups with secondary and higher education it was respectively 54\% (102) and 38\% (60) of women. The reverse of this phenomenon was observed in the study by Garwacka-Czachor et al. In this study conducted among 32626 women aged from 50-69 years old, it was observed that $14 \%$ (4 512) of women performed breast self-examination once a month. Moreover, there was a correlation between level of education and frequency of breast self-examination - the higher education a woman had, the more often she performed self-examination [27].

There is also some evidence that the most efficient tool in health education is to educate physicians.

\section{Conclusions}

1. The level of knowledge as well as attitudes concerning breast cancer risk factors in the most prone group (women 45+) should be constantly improved. Results suggest that education in this specific age group should be more efficient, dedicated only for these women and putting more effort on raising awareness of well-known breast cancer risk factors.

2. Results of the study indicate that existing women's education about BC could be ineffective - there was no $\mathrm{BC}$ risk factor chosen by $100 \%$ of women in any subgroup. Moreover, a great majority of women claimed that their knowledge about BC is good/very good, but it did not translate into health attitudes presented by them.

3. Strengthening the educational potential of medical personnel regarding $\mathrm{BC}$ risk factors could be beneficial for their patients and contribute to decreasing the incidence of BC. 


\section{Disclosures and acknowledgements}

1. The authors declare that they have no conflict of interest.

2. The authors would like to acknowledge all women that participated in the study survey and all individuals and organizations that helped distributing the questionnaires.

3. This work was not supported by any funding.

\section{References:}

1. Winters S, Martin C, Murphy D, Shokar NK. Breast cancer epidemiology, prevention, and screening. Prog Mol Biol Transl Sci. 2017; 151: 1-32. https://doi.org/10.1016/bs.pmbts.2017.07.002

2. World Health Organization. Regional Office for Europe [Internet]. Copenhagen: World Health Organization. Breastcancer [cited 2019 Jan 2]. Available from:http://www.euro.who.int/en/health-topics/noncommunicablediseases/cancer/news/news/2012/2/early-detection-of-common-cancers/breast-cancer

3. Wojciechowska U, Czaderny K, Ciuba A, Olasek P, Didkowska J. [Cancers in Poland in 2016]. Warszawa: Krajowy Rejestr Nowotworów, Zakład Epidemiologii i Prewencji Nowotworów; 2018 (in Polish).

4. Krajowy Rejestr Nowotworów [Internet]. Warszawa: Zakład Epidemiologii i Prewencji Nowotworów, Centrum Onkologii - Instytut. [Breast cancer in women (C50)] [cited 2019 Jan 2]. Available from: http://onkologia.org.pl/nowotwory-piersi-kobiet/ (in Polish).

5. Anand P, Kunnumakkara AB, Sundaram C, Harikumar KB, Tharakan ST, Lai OS, et al. Cancer is a preventable disease that requires major lifestyle changes. Pharm Res. 2008; 25(9): 2097-2116. https://doi.org/10.1007/s11095-008-9661-9

6. NIH National Cancer Institute [Internet]. Bethesda: National Cancer Institute; 2017. Obesity and cancer [cited 2019 Jan 20]. Available from: https://www.cancer.gov/about-cancer/causes-prevention/risk/obesity/ obesity-fact-sheet

7. Simone V, D’Avenia M, Argentiero A, Felici C, Rizzo FM, De Pergola G, et al. Obesity and breast cancer: molecular interconnections and potential clinical applications. The Oncologist. 2016; 21(4): 404-417. https://doi.org/10.1634/theoncologist.2015-0351

8. Friedenreich CM. Physical activity and breast cancer: review of the epidemiologic evidence and biologic mechanisms. Recent Results Cancer Res. 2011; 188: 125-39. https://doi.org/10.1007/978-3-642-10858-7_11

9. The American Cancer Society Medical and Editorial Content Team. Lifestyle-related breast cancer risk factors [Internet]. Atlanta: American Cancer Society; 2017 [cited 2019 Jan 2]. Available from: https://www. cancer.org/cancer/breast-cancer/risk-and-prevention/lifestyle-related-breast-cancer-risk-factors.html

10. McDonald JA, Goyal A, Terry MB. Alcohol intake and breast cancer risk: weighing the overall evidence. Current Breast Cancer Reports. 2013; 5(3): 208-221. https://doi.org/10.1007/s12609-013-0114-z

11. Liu Y, Nguyen N, Colditz GA. Links between alcohol consumption and breast cancer: a look at the evidence. Women's Health. 2015; 11(1): 65-77. https://doi.org/10.2217/WHE.14.62

12. Ministerstwo Zdrowia [Internet]. Warszawa: Ministerstwo Zdrowia. [Breast cancer prevention program] [cited 2019 Jan 2]. Available from: https://www.gov.pl/web/zdrowie/program-profilaktyki-raka-piersimammografia (in Polish).

13. Jokiel M, Bielska-Lasota M. [Breast cancer risk factors. Possibilities of primary cancer prevention]. Przegl Epidemiol. 2010; 64: 435-438 (in Polish).

14. Tazhibi M, Feizi A. Awareness levels about breast cancer risk factors, early warning signs, and screening and therapeutic approaches among Iranian adult women: a large population based study using latent class analysis. Biomed Res Int. 2014 Sep 11; 2014: 306352. https://doi.org/10.1155/2014/306352

15. Liu Y, Nguyen N, Colditz GA. Links between alcohol consumption and breast cancer: a look at the evidence. Women's Health. 2015; 11(1): 65-77. https://doi.org/10.2217/WHE.14.62

16. Państwowa Agencja Rozwiązywania Problemów Alkoholowych [Internet]. Warszawa: Państwowa Agencja Rozwiązywania Problemów Alkoholowych. [Women and alcohol] [cited 2019 Jan 10]. Available from: http://www.parpa.pl/index.php/szkody-zdrowotne-i-uzaleznienie/kobiety-i-alkohol (in Polish).

17. Neuhouser ML, Aragaki AK, Prentice RL, Manson JE, Chlebowski R, Carty CL, et al. Overweight, obesity, and postmenopausal invasive breastcancer risk: a secondary analysis of the Women's Healthinitiative randomized clinical trials. JAMA Oncology. 2015; 1(5): 611-621. https://doi.org/10.1001/jamaoncol.2015.1546

18. La Vecchia C, Giordano SH, Hortobagyi GN, Chabner B. Overweight, obesity, diabetes, and risk of breast cancer: interlocking pieces of the puzzle. The Oncologist. 2011; 16(6): 726-729.

https://doi.org/10.1634/theoncologist.2011-0050 
19. Zgliczyński WS. [Overweight and obesity in Poland]. Infos. 2017; 4(227) (in Polish).

20. Piekarzewska M, Wieczorkowski R, Zajenkowska-Kozłowska A. [Health condition of the Polish population in 2014]. Warszawa: Główny Urząd Statystyczny; 2016 (in Polish).

21. World Health Organization [Internet]. Geneva: World Health Organization. Physical activity [cited 2019 Jan 25]. Available from: https://www.who.int/dietphysicalactivity/pa/en/

22. Lynch BM, Neilson HK, Friedenreich CM. Physical activity and breast cancer prevention. Recent Results Cancer Res. 2011; 186: 13-42. https://doi.org/10.1007/978-3-642-04231-7_2

23. World Health Organization. Poland physical activity factsheet [Internet]. Copenhagen: World Health Organization Regional Office for Europe; 2014 [cited 2019 Jan 25]. Available from: http://www.euro.who. int/__data/assets/pdf_file/0003/288120/POLAND-Physical-Activity-Factsheet.pdf?ua=1

24. Seely JM, Alhassan T. Screening for breast cancer in 2018-what should we be doing today?. Curr Oncol. 2018; 25(Suppl 1): S115-S124. https://doi.org/10.3747/co.25.3770

25. Myers ER, Moorman P, Gierisch JM, Havrilesky LJ, Grimm LJ, Ghate S, et al. Benefits and harms of breast cancer screening: a systematic review. JAMA. 2015; 314(15): 1615-1634. https://doi.org/10.1001/jama.2015.13183

26. Coleman C. Early detection and screening for breast cancer. Semin Oncol Nurs. 2017; 33(2): 141-155. https://doi.org/10.1016/j.soncn.2017.02.009

27. Garwacka-Czachor E, Maciejczyk A, Bębenek M. Breast self-exams in a group of women participating in mammography screening. Nowotwory J Oncol. 2016; 66: 445-449. https://doi.org/10.5603/NJ0.2016.0080 